\title{
Expression of hepatocyte growth factor receptor (c-met) mRNA in primary cultures of human hepatocytes
}

\author{
S Hirono, S Afford, A J Strain
}

\begin{abstract}
Aim-To investigate the regulation of hepatocyte growth factor (HGF) receptor (c-met) gene expression in isolated primary human hepatocytes.

Methods-Primary hepatocytes were maintained in monolayer culture for up to 72 hours in serum-free medium. They were treated with growth factors and the level of HGF, c-met and reduced glyceraldehyde-phosphate dehydrogenase mRNA expression determined by northern blot analysis.

Results-Hepatocytes expressed a single 9 kilobase c-met gene transcript whilst HGF mRNA analysis was negative. Addition of HGF and epidermal growth factor, both potent mitogens for human hepatocytes, enhanced c-met mRNA expression approximately twofold within 24 hours, after which levels returned to normal. In nongrowth factor treated cells, transforming growth factor- $\beta$ (TGFß) had little effect upon c-met mRNA levels. However, TGFB inhibited the HGF induced increase in cmet mRNA levels.

Conclusions-These results indicate that hepatocytes which proliferate in response to HGF demonstrate levels of c-met mRNA which are subject to growth factor modulation and suggest an important means of growth regulatory control.

(f Clin Pathol: Mol Pathol 1995;48:M205-M209)
\end{abstract}

Keywords: Hepatocyte growth factor, c-met receptor, human hepatocytes, growth control.

Hepatocyte growth factor (HGF) is a disulfide linked heterodimeric polypeptide consisting of a heavy $\alpha$ subunit of $60 \mathrm{kDa}$ and a light $\beta$ subunit of $30 \mathrm{kDa} .{ }^{12}$ Molecular cloning of human and rat HGF cDNAs have been reported..$^{1-3} \mathrm{HGF}$ is a potent mitogen not only for isolated rat and human hepatocytes, ${ }^{4-6}$ but also for a variety of other epithelial cells including human biliary epithelial cells. ${ }^{78}$ In addition to its mitogenicity, $\mathrm{HGF}$ is also known to induce motility in certain cell types ${ }^{9}$ and to act as a tissue morphogen. ${ }^{10}$

Circulating concentrations of HGF rise following partial hepatectomy ${ }^{112}$ or administration of carbon tetrachloride in rats, ${ }^{13}$ and a direct correlation between circulating HGF concentrations and severity of human liver diseases has also been shown. ${ }^{14}$ Furthermore, several groups have reported some biological growth stimulatory activity in the liver following in vivo infusion. ${ }^{1516} \mathrm{HGF}$ messenger RNA (mRNA) has been localised in the liver by in situ hybridisation predominantly in lipocytes ${ }^{17} 18$ but is also present in Kupffer cells ${ }^{19}$ and sinusoidal endothelial cells. ${ }^{20}$ Taken together, this evidence indicates that HGF plays a fundamental role in the control of liver growth.

The HGF receptor has been identified as the c-met proto-oncogene ${ }^{2122}$ encoding a $50 \mathrm{kDa}$ extracellular $\alpha$ subunit and a transmembrane $145 \mathrm{kDa} \beta$ subunit with an intra-cellular tyrosine kinase domain. Following partial hepatectomy, c-met receptors are rapidly downregulated (within six hours) as a result of raised circulating $\mathrm{HGF}$ concentrations and receptor/ligand internalisation. ${ }^{23}$ However, during liver regeneration induced by carbon tetrachloride, c-met mRNA transcripts are elevated at six hours. ${ }^{24}$ Although the c-met postreceptor signalling events have been extensively studied in many cell types, ${ }^{25}$ less is known about the factors which control its expression in cells. Here, using a hepatocyte primary culture model, we have investigated the expression of c-met mRNA and its possible regulation by exogenous growth factors.

\section{Methods}

Materials used included: Collagenase A, dispase, hyaluronidase and DNAase supplied by Boehringer Mannheim. Epidermal growth factor (EGF) was purchased from Sigma, Poole, Dorset, and transforming growth factor- $\beta$ (TGF $\beta$ ) from R \& D Systems, Abingdon, Oxfordshire. Recombinant human HGF was from Dr T Ishii, Mitsubishi Kasei Corporation, Yokohama, Japan. Oligo(dT)-latex (OligotexdT30 super) was from Roche Pharmaceuticals, Welwyn Garden City, Herts. Rapid-Hyb buffer and Hybond-N membranes were from Amersham Life Science, Little Chalfont, Bucks. Human c-met cDNA (clone Pmet5) was obtained from the American type tissue collection and the human reduced glyceraldehyde-phosphate dehydrogenase (GAPDH) cDNA was kindly provided by Dr S Sakiyama (NIC, Tokyo, Japan).

ISOLATION OF HUMAN HEPATOCYTES

Normal liver tissue was obtained from the paediatric liver transplantation programme. Tissue had been preserved with University of Wisconsin fluid and maintained aseptically at $4^{\circ} \mathrm{C}$ for 12 to 24 hours before cell isolation. Hepatocytes were isolated by enzyme perfusion as 
previously described. ${ }^{626}$ Briefly, about $200 \mathrm{~g}$ of tissue was perfused at $50 \mathrm{ml} /$ minute, sequentially with $1000 \mathrm{ml} \mathrm{Ca}{ }^{2+} / \mathrm{Mg}^{2+}$ free phosphate buffered saline (PBS) containing $10 \mathrm{mM}$ HEPES (pH 7.4), $500 \mathrm{ml} 0.5 \mathrm{mM}$ EGTA (ethyleneglycol-bis-( $\beta$-aminoethylether)-N,N, $\mathrm{N}^{\prime}, \mathrm{N}^{\prime}$,-tetroacetic acid) in PBS and another $500 \mathrm{ml}$ of PBS. This was followed by $300 \mathrm{ml}$ of enzyme solution $(0.05 \%$ collgenase A, $0.038 \%$ hyaluronidase, $\quad 0.075 \%$ dispase, $0.005 \%$ DNAase in Hank's balanced salt solution with $5 \mathrm{mM} \mathrm{CaCl}_{2}$ ), which was recirculated for seven to eight minutes. The tissue was then minced with scissors in $200 \mathrm{ml}$ DMEM (Dulbecco's modified Eagle's medium) with $10 \%$ fetal calf serum and hand-stirred for a further $10 \mathrm{~min}$ utes. The cell suspension was filtered through $250 \mathrm{~mm}$ and $60 \mathrm{~mm}$ nylon meshes, washed three times in DMEM/ $\mathrm{CaCl}_{2} / 10 \% \mathrm{FCS}$ by centrifugation at $50 \times g$ for five minutes, and viability and yield assessed by trypan blue exclusion and hemocytometer counting. All

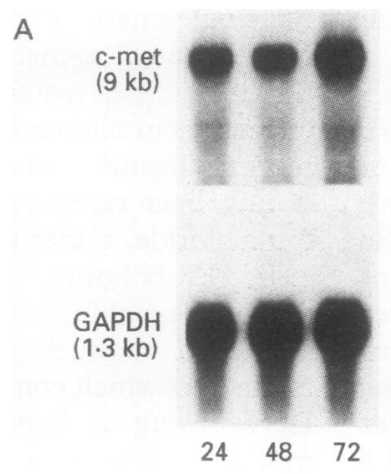

Time after plating (hours)

B

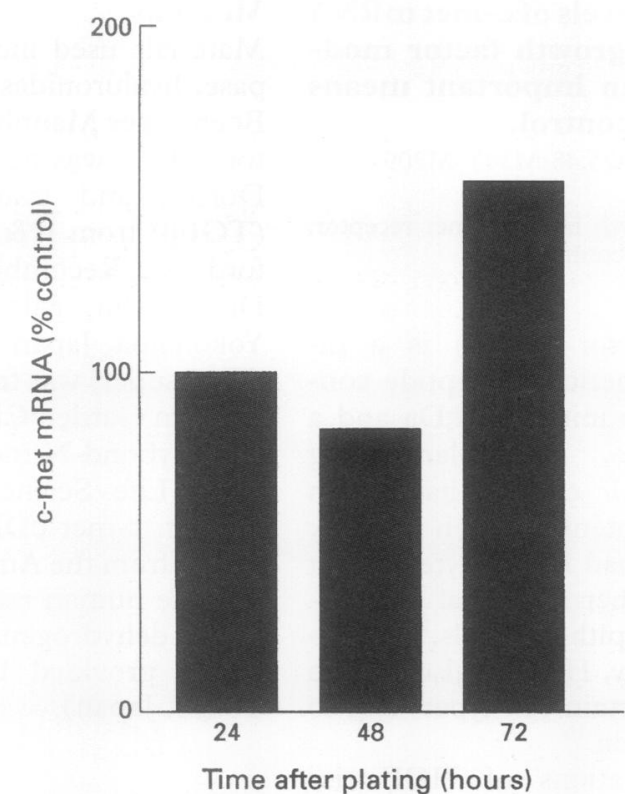

Figure 1 Northern blot analysis of c-met and GAPDH $m R N A$ prepared from human hepatocytes cultured with basal medium. Poly $A^{+} R N A$ (approximately $10 \mu \mathrm{g}$ ) was prepared from cells at the times indicated and membranes hybridised with c-met and GAPDH $m D N A$ probes $(A)$. Autoradiograms were scanned by laser densitometry and levels of c-met $m R N A$ expressed as the ratio of $c$-met/ $G A P D H(B)$. solutions were supplemented with $100 \mathrm{U} / \mathrm{ml}$ penicillin and $100 \mathrm{mg} / \mathrm{ml}$ streptomycin or $50 \mathrm{mg} / \mathrm{ml}$ gentamycin.

\section{CULTURE OF HEPATOCYTES}

Hepatocytes were cultured on rat-tail collagen coated $35 \mathrm{~mm}$ or $100 \mathrm{~mm}$ tissue culture dishes $(\times 105 \mathrm{cells} / \mathrm{ml})$ in $2 \mathrm{ml}$ and $15 \mathrm{ml} \mathrm{DMEM}$ with $10 \%$ FCS, respectively. ${ }^{66-28}$ After two hours, attached cells were washed twice with PBS, and were refed serum- and arginine-free Williams medium E supplemented with ornithine $(0.4 \mathrm{mM})$, insulin $(1 \mathrm{mM})$, hydrocortisone $(5.5 \mathrm{mM})$, penicillin $(100 \mathrm{U} / \mathrm{ml})$, and streptomycin $(100 \mathrm{mg} / \mathrm{ml})$. Medium was renewed every 24 hours and growth factors added at the times indicated.

\section{EXTRACTION OF POLYA ${ }^{+}$MRNA AND} NORTHERN BLOTTING

Cultures were washed twice with PBS at $4^{\circ} \mathrm{C}$ and then harvested and stored at $-70^{\circ} \mathrm{C}$. Total RNA was extracted by the acid-guanidinium thiocyanate-phenol-chloroform method. ${ }^{29}$ $\mathrm{PolyA}^{+}$mRNA was prepared using oligo dtlatex (Oligotex dt30 Super), samples were electrophoresed through formaldehyde-1\% agarose gels and blotted onto nylon membranes by the downward alkaline transfer method. ${ }^{30}$ Hybridisation was performed using a nick translated $\left({ }^{32} \mathrm{P}\right)$-labelled 500 base pair $E c o \mathrm{RI} /$ HindIII fragment of human c-met cDNA, a $2 \cdot 2$ kilobase $B a m \mathrm{H} 1 / K p n 1 \mathrm{HGF} \mathrm{cDNA}$ or 1.5 kilobase pair $E c o$ RI fragment of human GAPDH cDNA. Hybond-N membranes were pre-hybridised in Rapid-Hyb buffer at $65^{\circ} \mathrm{C}$ for 30 minutes. Denatured probes were added to the pre-hybridisation buffer, mixed well and incubated for two hours at $65^{\circ} \mathrm{C}$. Membranes were then washed in $2 \times \mathrm{SSC}, 0.1 \%$ SDS for 15 minutes at room temperature, then twice in $0.1 \times \mathrm{SSC}$ for 15 minutes at $65^{\circ} \mathrm{C}$. Hybridised membranes were autoradiographed for one to 14 days with intensifying screens at $-70^{\circ} \mathrm{C}$. Scanning laser densitometry was performed within the linear range of intensity of the film to quantify differences in mRNA expression. Membranes were stripped by washing in $0.1 \%$ SDS at $95^{\circ} \mathrm{C}$ for 30 minutes and then rehybridised with additional probes. Each experiment was repeated with cells isolated from three separate donors. Data presented are from one representative experiment.

\section{Results}

Human hepatocytes formed sub-confluent monolayers and morphologically were indistinguishable from rat hepatocytes as previously characterised. ${ }^{62627}$ The preparations were highly hepatocyte enriched, with $>95 \%$ of cells immunostaining positively with an antibody directed against the asialoglycoprotein receptor (data not shown). Although other cell types were present, they represented no more than $2 \%$ of the population.

In previous experiments with both rat and human hepatocytes exposure of cells to growth 

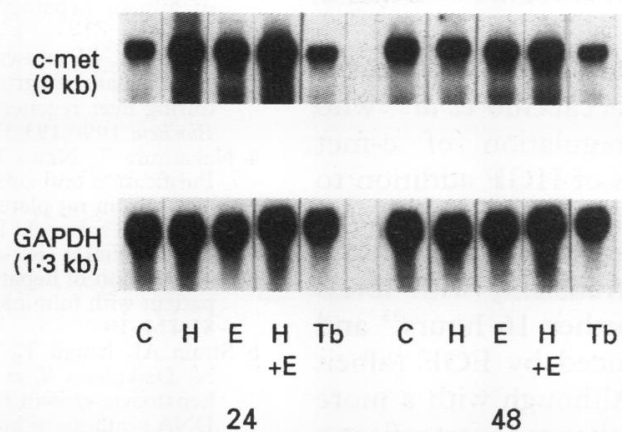

Time after addition (hours)
A

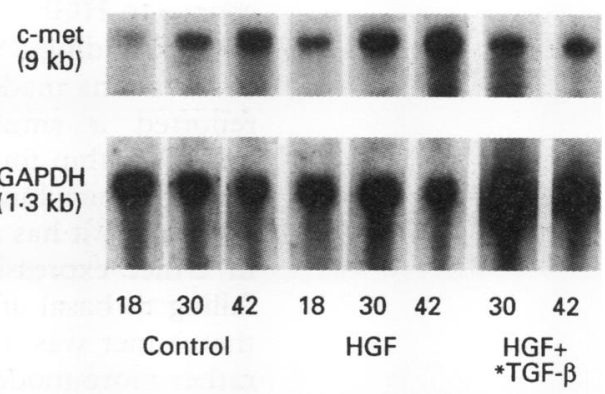

Time (hours) after addition of HGF

B

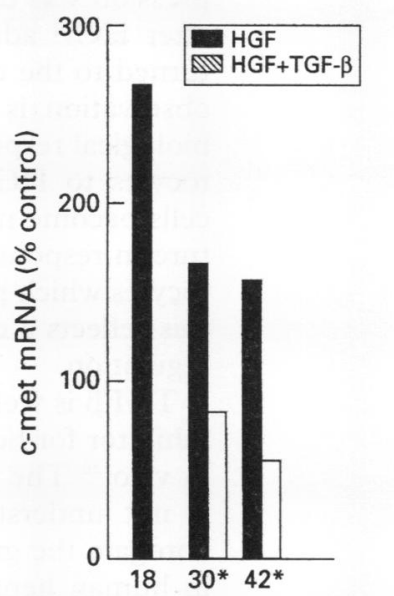

Time after addition of HGF (hours)

Figure 3 Effect of TGF $\beta$ on HGF enhanced $c$-met mRNA expression in hepatocytes. HGF was added to medium 24 hours after plating and RNA prepared at the times indicated. ${ }^{*} T G F \beta$ was added after a further delay of 18 hours (12 and 24 hours exposure to TGF $\beta$, respectively). Northern blot hybridisation was performed as before $(A)$. Levels of c-met $m R N A$ are expressed as the ratio of c-met/GAPDH and compared with controls (expressed as 100\%) at each indicated time (B).

the medium at 24 hours after plating and TGF $\beta$ added after a further 18 hours. As shown in figs $3 \mathrm{~A}$ and $3 \mathrm{~B}, \mathrm{HGF}$ increased c-met mRNA expression by $2 \cdot 8,1.6$ and 1.5 -fold at 18,30 and 42 hours, respectively. Addition of TGF $\beta$ resulted in a decrease in c-met mRNA levels to below that of cells at 30 and 42 hours after addition of HGF (12 and 24 hours after addition of TGF $\beta$, respectively). the level of GAPDH mRNA expression (fig $1 B)$. Using the same RNA preparations, we have been unable to detect specific HGF mRNA transcripts (data not shown).

Within 24 hours of treatment with either HGF or EGF, c-met mRNA expression was elevated 2 to $2 \cdot 4$-fold in hepatocytes (figs $2 \mathrm{~A}$ and $2 \mathrm{~B}$ ). HGF and EGF added together had no further effect. On the other hand, TGF $\beta$ treated cells demonstrated similar or slightly decreased c-met mRNA levels compared with controls. The growth factor induced elevation of c-met mRNA expression had returned to control levels 48 hours after addition (figs $2 \mathrm{~A}$ and $2 \mathrm{~B}$ ).

Finally, we investigated the effect of TGF $\beta$ on $\mathrm{HGF}$ induced c-met mRNA expression. In this series of experiments HGF was added to

\section{Discussion}

In the present study, we have sought to investigate the regulation of $\mathrm{HGF}$ receptor (cmet) expression in cultured human hepatocytes. We have successfully demonstrated a single specific c-met mRNA transcript (9 kilobases) in cells and that the mRNA levels appear to be upregulated by both EGF and HGF and downregulated by TGF $\beta$. The failure to detect HGF transcripts indicates a low level of non-parenchymal cell contamination of these cultures, as the latter are responsible for HGF expression in the liver. ${ }^{17-20}$ Thus, it seems likely that transcriptional control of c-met is one 
means whereby hepatocytes regulate their response to HGF.

Our findings are consistent with recent observations made by Boccacchio et al ${ }^{32}$ who reported a similar upregulation of c-met mRNA within four hours of HGF addition to A549 human lung adenocarcinoma cells. Interestingly, it has also been found that the rise in c-met expression is transient, with levels falling to basal after a further 16 hours $^{33}$ and that c-met was also induced by EGF (albeit rather more modestly). Although with a more rapid time course, these changes may reflect a common mechanism of regulation in the two cell types. This mechanism may not be universal, however, because c-met mRNA expression was downregulated up to eight hours after HGF addition to MDCK cells and returned to the control level at 27 hours. ${ }^{34}$ This observation is perhaps not surprising as the biological responses of MDCK cells and hepatocytes to $\mathrm{HGF}$ are quite different. MDCK cells become more motile and disperse in culture in response to $\mathrm{HGF}^{9}$ in contrast to hepatocytes which proliferate. ${ }^{4-6}$ Thus, it is possible this reflects a different mechanism of receptor regulation.

TGF $\beta$ is well recognised as a potent growth inhibitor for hepatocytes both in vitro ${ }^{4035}$ and in vivo. ${ }^{36}$ The mechanism of action, however, is not understood. The ability of TGF $\beta$ to abrogate the growth factor induction of $\mathrm{c}-\mathrm{met}$ in human hepatocytes suggests an interesting regulatory mechanism of growth inhibition in vitro which has previously not been reported in primary cultured hepatocytes. This mechanism is currently under investigation.

Clearly, it is also important to determine receptor expression at the translational level by ligand binding studies before identifying the major control step. In rat hepatocyte cultures HGF ligand binding is rapidly downregulated within two hours of HGF treatment reflecting receptor internalisation followed by recovery within a further 20 hours, ${ }^{37}$ a pattern which is also seen in the regenerating liver following partial hepatectomy. ${ }^{23}$ The recovery in vitro was reduced by cycloheximide suggesting that de novo protein synthesis was necessary. ${ }^{23}$ The time scale of this response in rat hepatocytes is consistent with the increase in human hepatocyte c-met mRNA expression observed in the present study and therefore with the possibility that this increase may also result in enhanced synthesis of receptor protein. Using the human hepatocyte culture system, determination of cmet protein expression is currently underway. These studies offer an insight into the means whereby cells may regulate their responsiveness to growth factors.

We wish to thank Ms J Fear for technical support and Dr T Ishii, Mitsubishi Kasei Corp, Yokohama, Japan, for supplying recombinant HGF. The antibody directed against the asialoglycoprotein receptor was a gift from $\mathrm{Dr} I \mathrm{G}$ McFarlane, Institute of Liver Studies, Kings College London, UK. Th work was financially supported by The Wellcome Trust.

1 Miyazawa K, Tsubouchi H, Naka D, Takahashi K, Okigaki $\mathrm{M}$, Arakaki N, et al. Molecular cloning and sequence analysis of cDNA for human hepatocyte growth factor. Biochem Biophys Res Commun 1989;163:967-73.

2 Nakamura T, Nishizawa T, Hagiya M, Seki T, Shimonishi
M, Sugimura A, et al. Molecular cloning and expression of human hepatocyte growth factor. Nature 1989;342 $440-3$.

3 Okajima A, Miyazawa K, Kitamura N. Primary structure of rat hepatocyte growth factor and induction of its mRNA during liver regeneration following hepatic injury. Eur $f$ Biochem 1990;193:375-81.

4 Nakamura T, Nawa K, Ichihara A, Kaise N, Nishino T Purification and sub-unit structure of hepatocyte growth Purification and sub-unit structure of hepatocyte growth

5 Gohda E, Tsubouchi H, Nakayama H, Hirono S, Sakiyama $\mathrm{O}$, Takahashi $\mathrm{K}$, et al. Purifation and partial characterisation of hepatocyte growth factor from plasma of patient with fulminant hepatic failure. 7 Clin Invest 1989 81:414-19.

6 Strain AJ, Ismail T, Tsubouchi H, Hishida T, Kitamura $\mathrm{N}$, Daikuhara $\mathrm{Y}$, et al. Native and recombinant human hepatocyte growth factors are highly potent promoters of DNA synthesis in both human and rat hepatocytes. $7 \mathrm{Clin}$ Invest 1991;87:1853-7.

7 Kan M, Zhang G, Zarnegar R, Myoken Y, Michalopoulos GK, McKeehan WL, et al. Hepatocyte growth factor/ Hepatopoeitin A stimulates the growth of rat kidney proximal tubule cells (RPTE), rat nonparenchymal liver cells, imal tubule cells (RPTE), rat nonparenchymal liver cells,
human melanoma cells, mouse keratinoctytes and stimhuman melanoma cells, mouse keratinoctytes and stim-
ulates anchorage-independent growth of SV-40 transulates anchorage-independent growth of SV-40 transformed

8 Joplin R, Hishida T, Tsubouchi H, Daikuhara Y, Ayres R, Neuberger JM, et al. Human intrahepatic biliary epithelial cells proliferate in vitro in response to human hepatocyte growth factor. 7 Clin Invest 1992;90:1284-9.

9 Weidner KM, Hartmann G, Naldini L, Comoglio PM, Sachs $\mathrm{M}$, Fonatsch $\mathrm{C}$, et al. Molecular characterisation of HGF-SF and its role in cell motility and invasion. In: Goldberg ID, Rosen EM, eds. Hepatocyte growth factorGoldberg ID, Rosen EM, eds. Hepatocyte growth factor-
scatter and the c-met receptor. Basel: Birkhauser Verlag, scatter factor and
1993:311-28

10 Montesano R, Matsumooto K, Nakamura T, Orci L. Identification of a fibroblast-derived epithelial morphogen as hepatocyte growth factor. Cell 1991;67:901-8.

11 Michalopoulos G, Houck KA, Dolan ML, Luetteke NC. Control of hepatocyte replication by two serum factors. Cancer Res 1984;44:4414-19.

12 Nakamura T, Nawa K, Ichihara A. Partial purification and characterisation of hepatocyte growth factor from serum of hepatectomised rats. Biochem Biophys Res Commun 1984;122:1450-9.

13 Gohda E, Hayashi Y, Kawaida A, Tsubouchi H, Yamamoto I. Hepatotrophic growth factor in blood of mice treated with carbon tetrachloride. Life Sci 1990;46:1801-8.

14 Tsubouchi H, Niitani Y, Hirono S, Nakayama H, Gohda $\mathrm{E}$, Arakaki N, et al. Levels of the human hepatocyte growth factor in serum of patients with various liver disease determined by an enzyme-linked immunosorbent assay. Hepatology 1991;13:1-5.

15 Webber EM, Godowski PJ, Fausto N. In vivo response of hepatocytes to growth factors requires an initial priming stimulus. Hepatology 1994;19:489-97.

16 Fujiwara K, Nagoshi S, Ohno A, Hirata K, Ohta Y, Mochida $\mathrm{S}$, et al. Stimulation of liver growth by exogenous human hepatocyte growth factor in normal and partially hepahepatocyte growth factor in normal and partia

17 Ramadori G, Neubauer K, Odenthal M, Nakamura $T$, Knittel T, Schwogler S, et al. The gene of hepatocyte growth factor is expressed in fat-storing cells of rat liver and is down-regulated during cell growth and by transforming growth factor $\beta$. Biochem Biophys Res Commun 1992;183 739-42.

18 Schirmacher P, Geerts A, Pietrangelo A, Dienes HP, Rogler CE. Hepatocyte growth factor/hepatopoeitin $A$ is expressed in fat-storing cells from rat liver but not myofibroblast-like cells derived from fat-storing cells. Hepatology 1992;15:5-11.

19 Noji S, Tashiro K, Koyama E, Nohno T, Ohyama K, Taniguchi $\mathrm{S}$, et al. Expression of hepatocyte growth factor gene in endothelial and Kupffer cells of damaged rat livers gene in endothelial and Kupffer cells of damaged rat livers
as revealed by in situ hybridisation. Biochem Biophys Res as revealed by in situ hyb
Commun 1990;173:42-7.

20 Maher J. Cell specific expression of hepatocyte growth factor in rat liver. $\mathcal{f}$ Clin Invest 1993;91:2244-52.

21 Bottaro DP, Rubin JS, Faletto DL, Chan AM-L, Kmiecik TE, Van de Woude GF, et al. Identification of the hepatocyte growth factor as the c-met proto-oncogene. Science 1991;251:802-4.

22 Naldini L, Weidner KM, Vinga E, Gaudino G, Bardeli A, Ponzetto C, et al. Scatter factor and hepatocyte growth factor are indistinguishable ligands for the met receptor. $E M B O \mathcal{f} 1991 ; \mathbf{1 0}: 2876-8$

23 Tajima $\mathrm{H}$, Higuchi $\mathrm{O}$, Mizuno $\mathrm{K}$, Nakamura T. Tissue distribution of hepatocyte growth factor receptor and its exclusive down-regulation in a regenerating organ after exclusive down-regulation in a regen
injury. $\mathcal{f}$ Biochem 1992;111:401-6.

24 Ito T, Hayashi N, Horimoto M, Sasaki Y, Tanaka Y, Kaneko $\mathrm{A}$, et al. Expression of the c-met/hepatocyte growth factor gene during rat liver regeneration induced by carbon tetrachloride. Biochem Biophys Res Commun 1993;190: $870-4$

25 Comoglio PM. Structure, biosynthesis and biochemical properties of the HGF receptor in normal and malignan cells. In: Goldberg ID, Rosen EM, eds. Hepatocyte growth factor-scatter factor and the c-met receptor. Basel: Birkhauser Verlag, 1993:131-65.

26 Ismail T, Howl J, Wheatley M, McMaster P, Neuberger JM, Strain AJ. Growth of normal human hepatocytes in 
primary culture: effect of hormones and growth factors on DNA synthesis. Hepatology 1991;14:1076-82.

27 Strain AJ, McGowan JA, Bucher NLR. Stimulation of DNA synthesis in primary cultures of rat hepatocytes by rat platelet-associated substances. In Vitro 1982;18:108-16.

$28 \mathrm{McG}$ owan JA, Strain AJ, Bucher NLR. DNA synthesis in primary cultures of adult rat hepatocytes in a defined primary cultures of adult rat hepatocytes in a defined medium: effects of epidermal growth factor, insulin, glu-

29 Chomczynski P, Sacchi N. Isolation of RNA using one step acid guanidinium thiocyanate-phenol-chloroform exacid guanidinium thiocyanate-phenol

traction. Anal Biochem 1987;162:156-9.
30 Chomczynski P. One hour downward alkaline capillary transfer for blotting of DNA and RNA. Anal Biochem 1992;201:134-9.

31 Strain AJ, Frazer A, Hill DJ, Milner RDG. Transforming growth factor $\beta$ inhibits DNA synthesis in hepatocytes from normal and regenerating liver. Biochem Biophys Res Commun 1987;145:436-42.

32 Boccacchio C, Gaudino G, Gambarotta G, Galimi F, Com oglio PM. Hepatocyte growth factor (HGF) receptor exoglio PM. Hepatocyte growth factor (HGF) receptor ex-
pression is inducible and is part of the delayed-early pression is inducible and is part of the delayed-
33 Ishibashi K, Sasaki S, Sakamoto H, Nakamura Y, Hata T, Nakamura $\mathrm{T}$, et al. Hepatocyte growth factor is a paracrine factor for renal epithelial cells: stimulation of DNA synthesis and Na,K-ATPase activity. Biochem Biophys Res Commun 1992;182:960-5.

34 Nakamura $T$, Tomita $T$, Hirai $R$, Yamaoka $K$, Kaji $K$, Ichihara A. Inhibitory effect of transforming growth factor $\beta$ on DNA synthesis of adult rat hepatocytes in factor $\beta$ on DNA synthesis of adult rat hepatocytes in 133:1042-50.

35 Braun L, Mead JE, Danielpour D, Wu J, Roberts AB, Fausto N. Transforming growth factor $\beta$ mRNA increases during liver regeneration: a possible paracrine mechanism of growth regulation. Proc Natl Acad Sci USA 1988;85: $1539-43$.

36 Russell WE, Coffey RJ, Ouellette AJ, Moses HL. Type $\beta$ transforming growth factor reversibly inhibits the early proliferative responses to partial hepatectomy in the rat. Proc Natl Acad Sci USA 1988;85:5126-30.

37 Mizuno K, Higuchi O, Tajima H, Yonemasu T, Nakamura $\mathrm{Y}$. Cell density regulation of hepatocyte growth factor receptor on adult rat hepatocytes in primary culture. $f$ Biochem 1993;114:96-102. 